\title{
Antena J-Pole Berbahan Aluminium Rod pada Komunikasi Handy Talky
}

\author{
DWI ARYANTA , LITA LIDYAWATI , MULIA EZA AKMAL
}

Teknik Elektro Institut Teknologi Nasional

Email: dwiaryanta@gmail.com

Received 22 Juli 2018 | Revised 18 Agustus 2018 | Accepted 30 September 2018

\begin{abstract}
ABSTRAK
Perangkat komunikasi Handy Talky (HT) yang ada saat ini masih relatif banyak dipergunakan mengingat nilai ekonomis yang dimilikinya. Pada beberapa tipe, perangkat ini memiliki kekurangan dalam hal jangkauan. Penelitian ini bertujuan untuk merealisasikan dua buah antena J-Pole menggunakan bahan aluminium rod yang diaplikasi pada perangkat HT pada frekuensi $144 \mathrm{MHz}$. Hasil realisasi kedua antena diperoleh gain antena 1 dan 2 masing-masing sebesar 6,23 dB dan 6,34 $d B$, dimana VSWR didapatkan sebesar 1,27 dan 1,16. Nilai Return Loss pada antena 1 dan 2 masing-masing sebesar -18,58 dB dan -22,48 dB. Antena J-Pole yang diaplikasikan dapat menambah jarak jangkau HT yang digunakan sejauh 2,46 km dari penggunaan antena existing.
\end{abstract}

Kata kunci: J-Pole, Handy Talky, VSWR, Gain, Omnidirectional.

\section{ABSTRACT}

Handy Talky (HT) communication devices that exist today are still relatively widely used considering the economic value it has. In some types, this device has a deficiency in terms of range. This study aims to realize two J-Pole antennas using aluminum rod material applied to HT devices at a frequency of $144 \mathrm{MHz}$. The second antenna gain result obtained antenna gain 1 and 2 respectively equal to $6.23 d B$ and 6.34 $d B$, where VSWR got equal to 1.27 and 1.16. Return Loss values on antennas 1 and 2 are respectively $-18.58 d B$ and $-22.48 d B$. The applied J-Pole antenna can increase the range of HT used as far as $2.46 \mathrm{~km}$ from the use of existing antenna.

Keywords: J-Pole, Handy Talky, VSWR, Gain, Omnidirectional 


\section{PENDAhUlUAN}

Sejalan dengan kemajuan teknologi, media komunikasi yang digunakan mengalami perkembangan. Dimulai dari komunikasi satu arah dengan menggunakan sandi hingga menggunakan radio ataupun televisi, atau untuk komunikasi dua arah yang menggunakan telepon hingga sekarang dapat menggunakan telepon seluler (ponsel). Masyarakat saat ini lebih banyak menggunakan komunikasi dua arah seperti ponsel, Handy Talky (HT), dan perangkat komunikasi bergerak lainnya. Dilihat dari segi biaya penggunaan dan frekuensinya, HT memiliki keuntungan lain dari sisi kebutuhan daripada ponsel, dimana salah satunya adalah tidak memerlukan biaya dalam melakukan komunikasi.

HT merupakan salah satu alat komunikasi yang menggunakan gelombang radio, yang merupakan komunikasi simpleks, dimana komunikasi dilakukan dua arah secara bergantian (tidak simultan). Selain tidak menggunakan pulsa, salah satu keistimewaan yang dimiliki HT adalah tidak memerlukan sebuah Base Tranceiver Station (BTS). HT dapat menggunakan berbagai macam antena sebagai media pengirim dan penerimanya, salah satunya ialah antena J-Pole. Karakteristik antena J-Pole yang memiliki pola radiasi omnidirectional sangat sesuai dengan kebutuhan komunikasi HT. (Krismawardana, 2015)

Pada penelitian sebelumnya yaitu mengenai antena Super J-Pole untuk $70 \mathrm{~cm}$ Band dan $2 \mathrm{~m}$ Band dengan menggunakan frekuensi sebesar $435 \mathrm{MHz}$ untuk Band $70 \mathrm{~cm}$ oleh Ridwan Lesmana. Pada antena Super J-Pole dapat menghasilkan gain sebesar $6 \mathrm{~dB}$. Penelitian ini juga menggunakan beberapa frekuensi radio amatir yang berada di daerah Jakarta, yaitu pada frekuensi 438,02 MHz. (Lesmana, 2013)

Pada tahun 2014, Mulia Eza Akmal dari Politeknik Caltex Riau, melakukan pembuatan Antena J-Pole menggunakan radio transmitter bekerja pada frekuensi radio $144 \mathrm{MHz}$. Pengujian antena dilakukan dengan menggunakan software MMANA-Gal dan juga pengukuran secara langsung di laboratorium. Hasil pengukuran yang diperoleh yaitu VSWR yang bernilai 1,88 , gain antena sebesar 7,896 dB, dan bentuk pola radiasi omnidirectional. Antena J-Pole juga memiliki daya jangkau sejauh $2,35 \mathrm{~km}$. (Akmal, 2014)

Pada tahun 2015, Yoga Krismawardana, melakukan penelitian yang berjudul "Perancangan dan Analisis Antena J-Pole Dualband dengan Variasi Bentuk ' $\mathrm{T}$ ' untuk Komunikasi Radio Transceiver pada Pita VHF dan UHF". Antena tersebut dirancang pada frekuensi $146 \mathrm{MHz}$ menggunakan material kawat besi dengan diameter $4 \mathrm{~mm}$. Berdasarkan hasil pengujian, antena J-Pole-T memiliki frekuensi kerja pada $148 \mathrm{MHz}$ dengan nilai VSWR 1:1,1, sementara pada pita UHF didapatkan frekuensi kerja pada $454 \mathrm{MHz}$ dengan nilai VSWR 1:1,05. Pola radiasi antena J-Pole-T menunjukkan pola omnidirectional. Hasil pengujian menunjukkan bahwa antena J-Pole-T dapat memancarkan dan menerima sinyal sejauh 1,47 km pada pita VHF dan 930 meter pada pita UHF. (Krismawardana, 2015)

Peralatan HT berpotensi untuk dimanfaatkan lebih optimal dengan penggunaan antena yang memiliki karakteristik lebih baik, sehingga akan dapat meningkatkan kinerja khususnya dalam memperpanjang usia pakai perangkat, jarak jangkau dan kualitas pengiriman dan penerimaan yang lebih baik. Oleh karena itu, penulis bermaksud merancang dan merealisasikan antena JPole menggunakan material aluminium rod (pejal) untuk melihat kinerja antena dibandingkan dengan penelitian sebelumnya yang menggunakan material aluminium berongga. Pertimbangan lain penggunaan material pejal adalah memiliki ketahanan yang lebih baik dibandingkan dengan material berongga dalam mempertahankan bentuk dan ukuran antena J-Pole. 


\section{METODOLOGI PENELITIAN}

Penelitian dilaksanakan dengan beberapa tahapan pengerjaan, dimana parameter fisik antena dilakukan secara perhitungan, sedangkan untuk karakteristik antena dilakukan secara perhitungan, pengukuran langsung dan melalui software MMANA-Gal. Bagan alir metodologi pengerjaan penelitian tergambar pada Gambar 1.

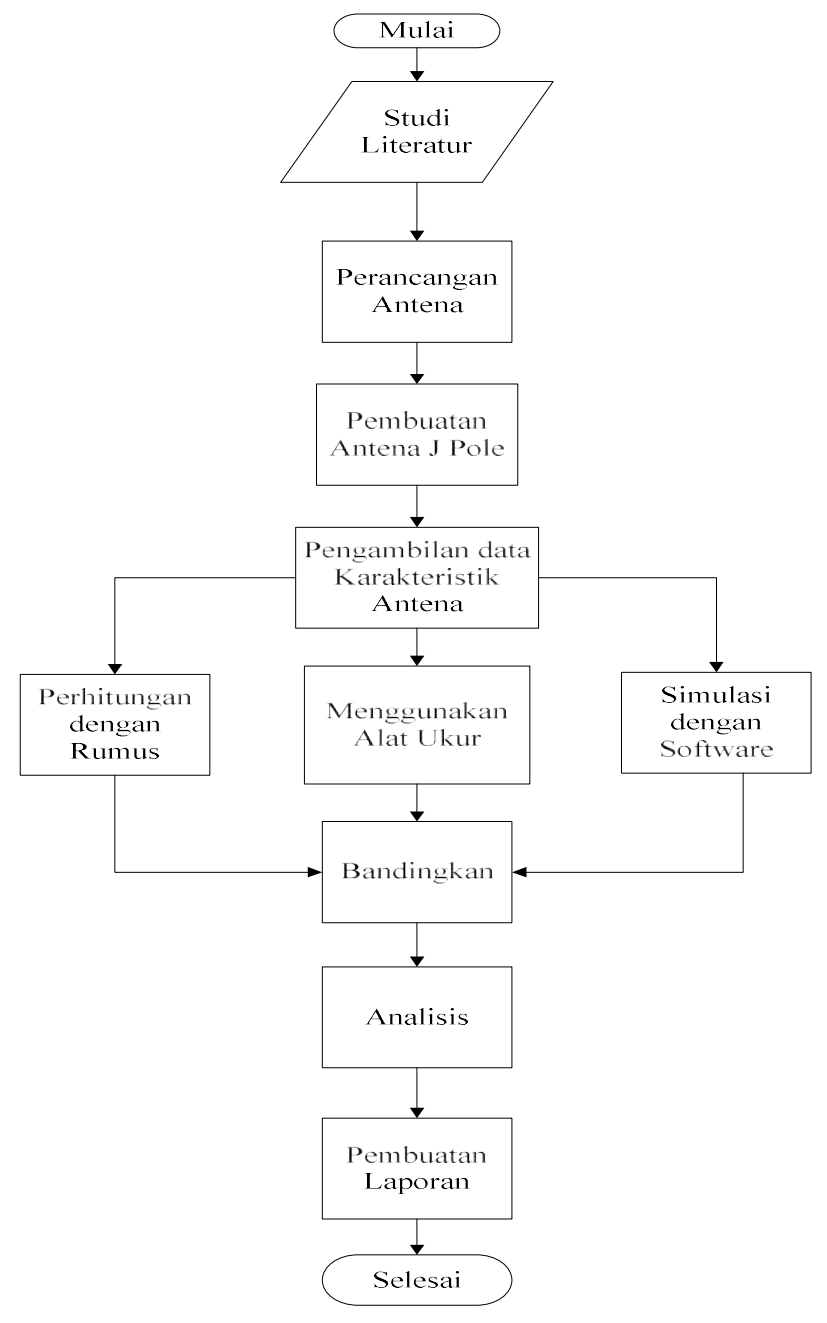

Gambar 1. Flowchart Pengerjaan

Pada blok perancangan antena terdapat dua metode yang digunakan, yaitu perhitungan teoritis dan software MMANA-Gal. Lalu pada pengukuran karakteristik antena akan dilakukan perbandingan antara perhitungan, pengukuran antena langsung dan simulasi. Data yang dapat dibandingkan antara lain: nilai daya dari antena J-Pole, nilai gain, pola radiasi, dan juga mengetahui frekuensi kerja antena J-Pole. Analisis kinerja antena J-Pole dilakukan melalui hasil pengukuran karakteristik antena, perhitungan teoritis, dan hasil simulasi menggunakan software MMANA-Gal.

\subsection{Perancangan Antena J-Pole}

Pada penelitian ini dilakukan perancangan antena J-Pole yang akan digunakan untuk komunikasi radio pada frekuensi $144 \mathrm{MHz}$, atau pada panjang gelombang sebesar 2,083 m. 
Panjang gelombang ini kemudian menjadi acuan untuk menentukan dimensi antena J-Pole, yaitu sepanjang 1 kali panjang gelombang, atau 208,3 cm.

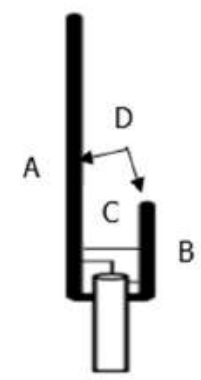

\section{Gambar 2. Dimensi Dasar Antena J-Pole}

Dimensi fisik antena J-Pole digambarkan seperti pada Gambar 2, merupakan desain dasar dari antena J-Pole, dimana dengan menggunakan bahan aluminium rod. Parameter dimensi A, B, C, dan D kemudian dirumuskan melalui persamaan berikut. (K4abt, 1996)

$$
\begin{aligned}
& \mathbf{A}=\frac{705}{F}[\text { feet }] \\
& \mathbf{B}=\frac{235}{F}[\text { feet }] \\
& \mathbf{C}=\frac{23}{F} \quad[\text { feet }] \\
& \mathbf{D}=\frac{22}{F} \quad[\text { feet }]
\end{aligned}
$$

Frekuensi kerja komunikasi radio yang digunakan adalah $144 \mathrm{MHz}$, sehingga melalui penggunaan Persamaan (1), (2), (3) dan (4), maka diperoleh panjang masing-masing bagian yaitu A memiliki panjang 4,89 feet $(1,47 \mathrm{~m})$, B memiliki panjang 1,625 feet $(0,49 \mathrm{~m})$, C memiliki panjang 0,16 feet $(0,048 \mathrm{~m})$, dan bagian $\mathbf{D}$ ialah memiliki panjang 0,15 feet $(0,045$ $\mathrm{m})$. Pencatuan antena J-Pole dilakukan dengan menghubungkan konduktor ke bagian A dan grounding terhubung ke bagian $\mathrm{B}$.

\subsection{Pengukuran Daya dan Pola Radiasi Antena}

Pengukuran daya antena dilakukan dengan skema seperti yang digambarkan pada Gambar 3, dimana pada Radio Transmitter dipasang antena Horn sebagai antena pemancar (Tx), dan pada Spectrum Analyzer dipasang antena J-Pole sebagai penerima (Rx). Peletakan ini pada pengukuran berikutnya dilakukan pembalikan posisi. Setelah mendapat nilai daya maka dilanjutkan dengan mengambil daya antena dengan cara memutar antena tersebut sejauh $360^{\circ}$ dan mengamati daya yang didapat setiap $10^{\circ}$ untuk mencari pola radiasinya. Pada pengukuran ini antena yang dipakai ialah antena Horn sebagai referensinya. Pengambilan data akan beberapa kali untuk memperoleh hasil yang optimal.

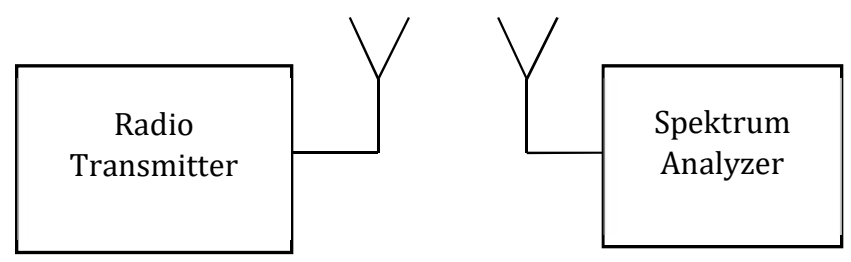




\section{Gambar 3. Pengukuran Daya Antena}

\subsection{Perhitungan Gain Antena}

Pengukuran gain antena J-Pole juga dapat menggunakan langkah sebelumnya seperti pada Gambar 3, dimana tujuannya di sini untuk mengetahui nilai daya yang didapat oleh antena JPole. Untuk mencari nilai gain antena dapat menggunakan Persamaan (5). (Selvan, 2006)

$$
G=\left(P_{t}-P_{s}\right)+G_{s}
$$

Dimana:

$G_{S}=$ nilai gain antena referensi (Horn)

$P_{S}=$ daya terima pada antena referensi (Horn)

$P_{t}=$ daya terima dari antena terukur (J-Pole)

\subsection{Pengukuran Impedansi, VSWR, dan Return Loss}

Nilai Voltage Standing Wave Ratio(VSWR) suatu antena, dapat diperoleh melalui perhitungan secara teori maupun dengan melakukan pengukuran langsung. Untuk mendapatkan nilai VSWR menggunakan perhitungan, maka harus diketahui berapa nilai dari koefisien refleksi. Koefisien refleksi ini terdiri atas impedansi awal dan impedansi beban. Impedansi beban sendiri dapat dilihat pada network analyzer sedangkan impedansi awal dapat dilihat dari kabel coaxial yang digunakan. Umumnya nilai impedansi dari saluran coaxia/yang digunakan bernilai $50 \Omega$ -

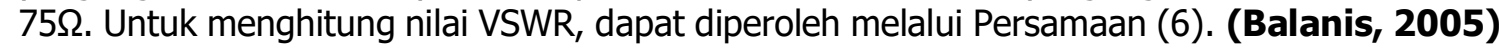

$$
\mathrm{VSWR}=\frac{1+\Gamma}{1-\Gamma}
$$

Dengan $\Gamma$ adalah nilai koefisien refleksi yang dapat dihitung menggunakan Persamaan (7).

$$
\Gamma=\frac{z_{L}-z_{0}}{z_{L}+z_{0}}
$$

Dimana $Z_{L}$ merupakan impedansi beban/antena dan $Z_{0}$ adalah impedansi instrinsik.

Return loss adalah salah satu parameter yang digunakan untuk mengetahui berapa banyak daya yang hilang pada beban dan tidak kembali sebagai pantulan. Retrurn loss terjadi karena bercampurnya gelombang yang ditransmisikan dan gelombang yang dipantulkan. Return loss juga dapat digunakan untuk melihat hilangannya suatu daya yang ditransmisikan dan seberapa besar daya pada sisi penerima (receiver). Kinerja antena akan semakin baik pada saat diperoleh nilai return loss yang semakin kecil. Hal ini dapat disimpulkan bahwa semakin sedikit daya yang hilang pada pentransmisian antena maka akan semakin baik antena tersebut. (Irfan, 2016)

\subsection{Pengukuran Jarak Jangkau}

Pada pengukuran jarak jangkau dimaksudkan untuk mengetahui kemampuan HT dalam berkomunikasi sampai dengan jarak tertentu, dimana kualitas komunikasi dikatakan masih layak. Hasil pengukuran jarak jangkau maksimum komunikasi HT nantinya akan dilakukan pembandingan antara saat menggunakan antena existing dengan penggunaan antena J-Pole hasil rancangan kepada kedua sisi HT. 


\section{HASIL PENELITIAN DAN ANALISIS}

\subsection{Pengukuran Return loss}

Pengukuran nilai return loss antena J-Pole dilakukan untuk melihat daya yang hilang pada pentransmisian karena ketidaksesuaian antara impedansi antena dengan sistem perangkat. Pengukuran dilakukan menggunakan Network Analyzer (NA) diperoleh hasil seperti pada Gambar 4, dimana nilai Return loss untuk J-Pole 1 sebesar -18,576 dB dan untuk J-Pole 2 sebesar $-22,478 \mathrm{~dB}$.

Hasil pengukuran return loss menunjukkan hasil yang baik, dimana nilai dari return loss yang baik adalah lebih kecil dari $-9,54 \mathrm{~dB}$. Batasan nilai return loss yang baik diperoleh untuk nilai VSWR $\leq 2$ sehingga dapat dikatakan nilai gelombang yang direfleksikan tidak terlalu besar dibandingkan dengan gelombang yang dikirimkan atau dengan kata lain, antara antena dengan saluran transmisi sudah matching. Nilai parameter ini menjadi salah satu acuan untuk melihat apakah antena sudah dapat bekerja pada frekuensi yang diharapkan atau tidak.

\section{(Ephirahmawati, 2013)}

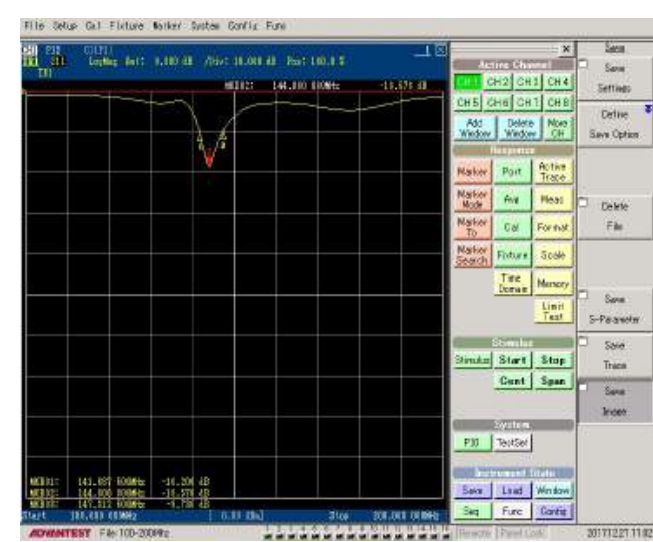

a). J-Pole 1

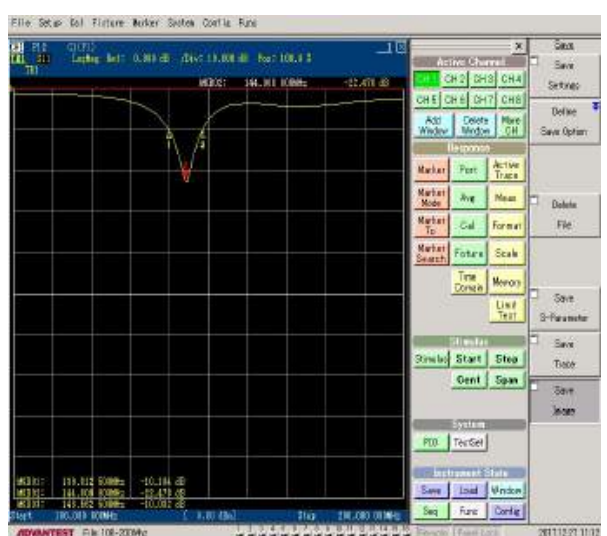

b). J-Pole 2

Gambar 4. Nilai Return Loss Hasil Pengukuran

Terdapat sedikit perbedaan nilai return loss pada kedua antena J-Pole yang telah dirancang, dimana dipengaruhi oleh peletakan konektor antena J-Pole. Optimasi kinerja antena dapat dilakukan melalui proses tunning antena J-Pole dimana dilakukan penyesuaian penempatan konektor pada titik catuan antena J-Pole.

\subsection{Analisis Impedansi dan VSWR}

Pada pengukuran untuk nilai VSWR ini ada tiga metode yang dilakukan, yaitu menggunakan perhitungan, menggunakan simulasi dan pengukuran. Pada metode perhitungan, terlebih dahulu menghitung nilai impedansi antena menggunakan Network Analyzer. Gambar 5 merupakan tampilan dari alat ukur Network Analyzeruntuk nilai impedansi pada antena J-Pole. Nilai impedansi dari Antena J-Pole pada frekuensi $144 \mathrm{MHz}$ adalah sebesar (39,489 - j0,8404) $\Omega$ untuk antena J-Pole 1 dan $(58,059-\mathrm{j} 1,02) \Omega$ untuk J-Pole 2. 


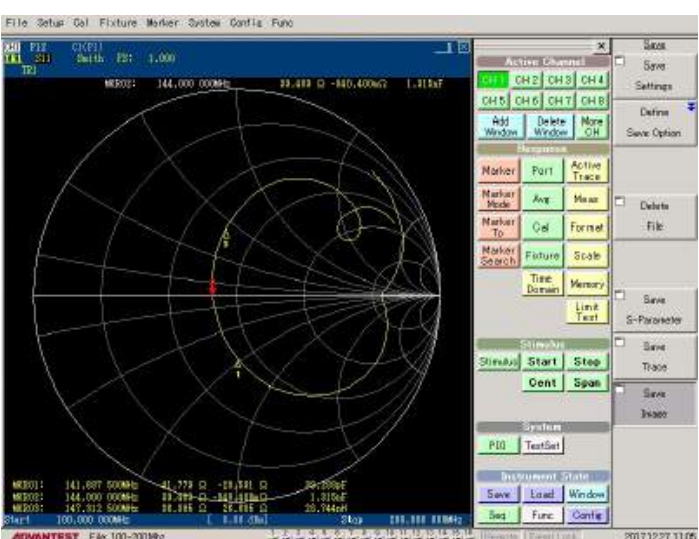

a). J-Pole 1

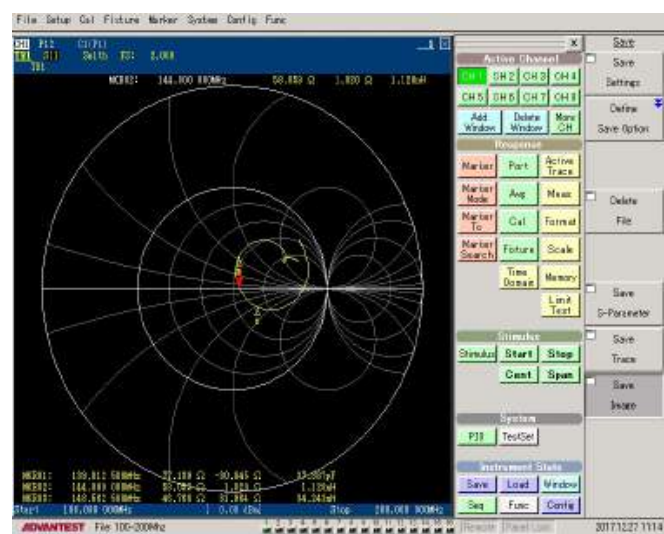

b). J-Pole 2

Gambar 5. Nilai Impedansi Hasil Pengukuran

Nilai impedansi antena digunakan untuk menghitung nilai koefisian refleksi dan VSWR masingmasing antena. Melalui perhitungan lebih lanjut diperoleh nilai koefisien refleksi J-Pole 1 sebesar $(0,12+j 0,1)(|\Gamma|=0,16)$ dan pada J-Pole 2 sebesar $\left(0,08+j 9,29.10^{-3}\right) \quad(|\Gamma|=0,08)$, sedangkan nilai VSWR J-Pole 1 sebesar 1,3 dan untuk J-Pole 2 sebesar 1,17. Nilai VSWR hasil pengukuran terlihat pada Gambar 6, dimana nilai VSWR dari antena J-Pole 1 bernilai 1,267 dan J-Pole 2 bernilai 1,162.

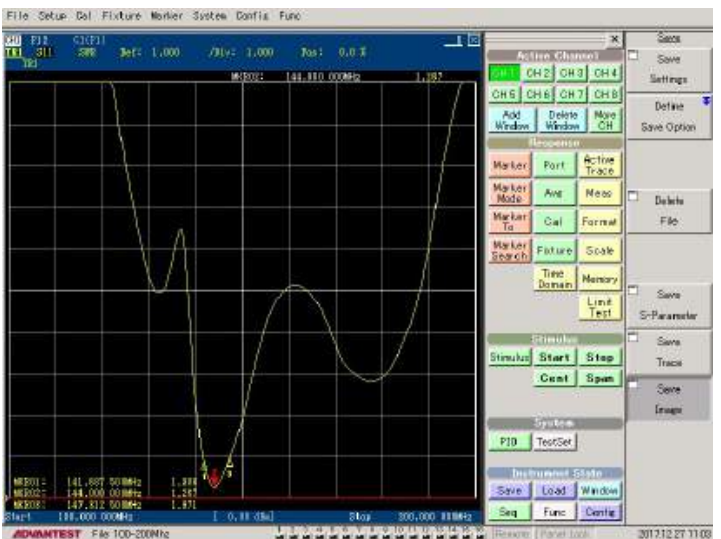

a). J-Pole 1

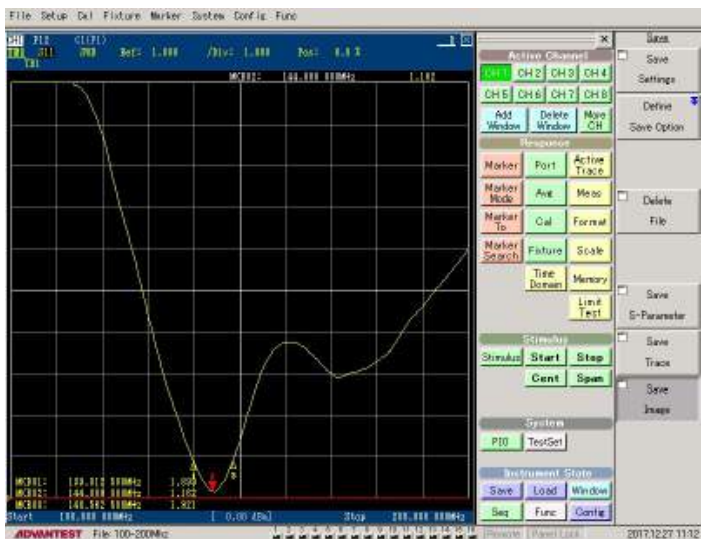

b). J-Pole 2

Gambar 6. Nilai VSWR Antena Hasil Pengukuran

Nilai VSWR hasil simulasi menggunakan software MMANA-GAL terlihat pada Gambar 7, dimana didapatkan nilai VSWR sebesar 1,03. Melalui tiga metode penentuan nilai VSWR, diperoleh nilai VSWR yang mendekati sama. 


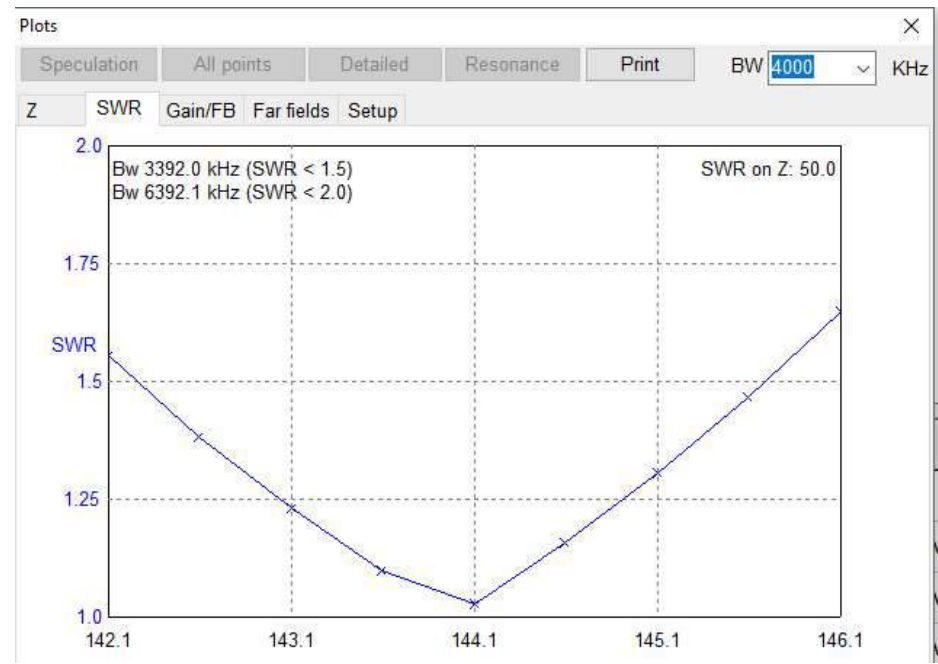

Gambar 7. Pengamatan Nilai VSWR Hasil Simulasi

Nilai VSWR hasil perhitungan, hasil pengukuran dan hasil siumlasi software MMANA-GAL menunjukkan nilai yang sudah sesuai dengan batasan nilai VSWR $\leq 2$, sehingga dapat dikatakan karakteristik antena J-Pole sudah memenuhi ketentuan.

\subsection{Analisis Gain}

Pengukuran penguatan (gain) antena menggunakan sejumlah peralatan yaitu Signal Generator, kabel coaxial, Spectrum Analyzer dan sebuah antena Horn (gain $6 \mathrm{~dB}$ ) sebagai antena referensi. Langkah pertama, antena Horn dihubungkan dengan Signal Generator dan antena J-Pole dihubungkan dengan Spectrum Analyzer. Langkah kedua adalah dengan membalik penempatan antena, dimana Antena J-Pole dihubungkan ke Signal Generator dan antena Horn dihubungkan ke Spectrum Analyzer. Nilai gain hasil perhitungan untuk antena JPole 1 adalah sebesar 6,23 dB dan J-Pole 2 sebesar 6,34 dB, sedangkan melalui penggunaan software MMANA-Gal seperti pada Gambar 8, diperoleh nilai gain antena J-Pole adalah sebesar $6,7 \mathrm{~dB}$.

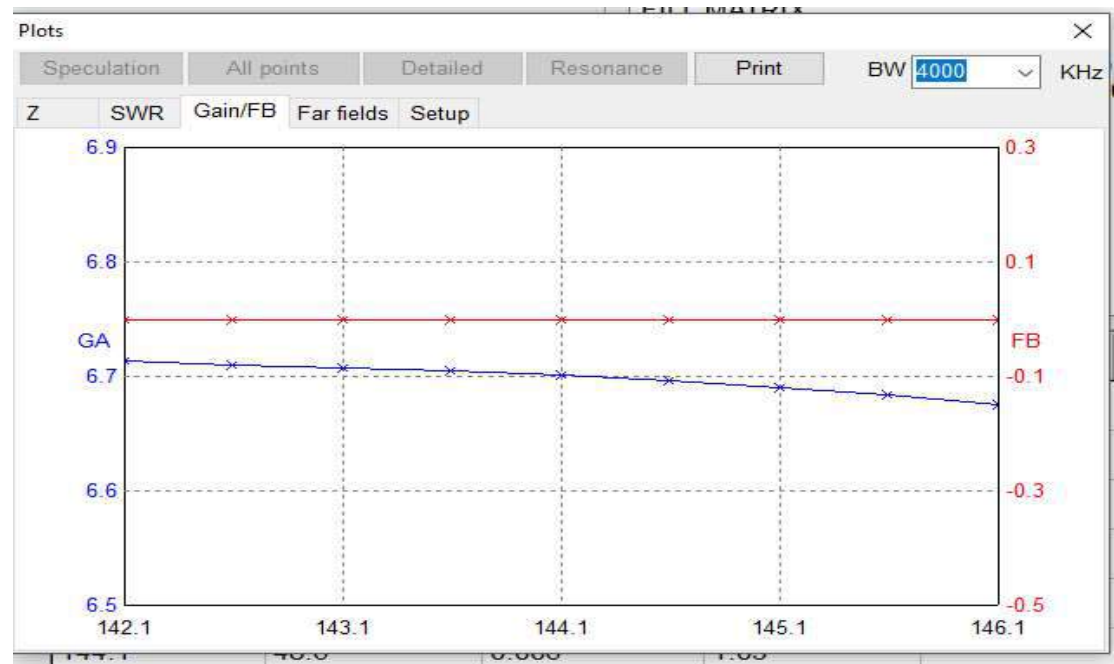

Gambar 8. Nilai Gain pada Software MMANA-Gal 
Melalui sejumlah metode untuk mengetahui karakteristik parameter antana J-Pole yang telah dilakukan, secara umum, hasil yang didapatkan tidak jauh berbeda. Perbedaan kecil terhadap hasil antara pengamatan melalui software dan melalui pengukuran menggunakan alat ukur lebih dikarenakan ketika pengukuran langsung terdapat banyak gangguan dari luar seperti ada gangguan gelombang radio lain (seluler dan wifi), loss kabel, konektor yang digunakan dan juga toleransi dari alat ukur tersebut, sedangkan pada penggunaan simulasi software, nilai yang didapat merupakan kondisi antena yang ideal.

\subsection{Analisis Pola Radiasi}

Pengukuran pola radiasi bertujuan untuk melihat dan juga membuktikan bahwa antena J-Pole memiliki pola radiasi omnidirectional. Proses pengukuran dilihat dari berapa besar level daya yang diterima antena J-Pole ketika antena diputar dari $0^{\circ}$ sampai $360^{\circ}$ dengan kelipatan $10^{\circ}$. Data hasil pengukuran daya terima untuk masing-masing antena J-Pole ditampilkan pada Tabel 1 dan Tabel 2, yang kemudian diplot pola radiasinya pada Gambar 9.

Tabel 1. Daya Terima pada Antena J-Pole 1 Berdasarkan Sudut

\begin{tabular}{|c|c|c|c|c|c|}
\hline Sudut $\left.\mathbf{(}^{\mathbf{0}}\right)$ & $\begin{array}{c}\text { Daya Terima } \\
(\mathbf{d B m})\end{array}$ & Sudut $\left.\mathbf{(}^{\mathbf{0}}\right)$ & $\begin{array}{c}\text { Daya Terima } \\
(\mathbf{d B m})\end{array}$ & Sudut $\mathbf{(}^{\mathbf{0}} \mathbf{)}$ & $\begin{array}{c}\text { Daya Terima } \\
(\mathbf{d B m})\end{array}$ \\
\hline 0 & -33.11 & 120 & -33.16 & 240 & -34.3 \\
\hline 10 & -41 & 130 & -35.39 & 250 & -37.2 \\
\hline 20 & -34.74 & 140 & -36.58 & 260 & -36.88 \\
\hline 30 & -35.23 & 150 & -35.41 & 270 & -35.29 \\
\hline 40 & -36.75 & 160 & -34.89 & 280 & -36.58 \\
\hline 50 & -34.93 & 170 & -36.96 & 290 & -34.65 \\
\hline 60 & -34.04 & 180 & -35.04 & 300 & -35.36 \\
\hline 70 & -33.24 & 190 & -34.73 & 310 & -34.29 \\
\hline 80 & -35.63 & 200 & -33.7 & 320 & -33.74 \\
\hline 90 & -35.95 & 210 & -33.56 & 330 & -35.66 \\
\hline 100 & -36.44 & 220 & -34.71 & 340 & -35.74 \\
\hline 110 & -34.27 & 230 & -35.72 & 350 & -34.2 \\
\hline
\end{tabular}

Tabel 2. Daya Terima pada Antena J-Pole 2 Berdasarkan Sudut

\begin{tabular}{|c|c|c|c|c|c|}
\hline Sudut $\left.\mathbf{(}^{\mathbf{}}\right)$ & $\begin{array}{c}\text { Daya Terima } \\
(\mathbf{d B m})\end{array}$ & Sudut $\mathbf{(}^{\mathbf{}} \mathbf{)}$ & $\begin{array}{c}\text { Daya Terima } \\
\mathbf{( d B m})\end{array}$ & Sudut $\left.\mathbf{(}^{\mathbf{0}}\right)$ & $\begin{array}{c}\text { Daya Terima } \\
(\mathbf{d B m})\end{array}$ \\
\hline 0 & -32.25 & 120 & -35.24 & 240 & -35.33 \\
\hline 10 & -32.57 & 130 & -36.52 & 250 & -34.7 \\
\hline 20 & -33.82 & 140 & -36.83 & 260 & -36.45 \\
\hline 30 & -33.61 & 150 & -35.76 & 270 & -34.61 \\
\hline 40 & -32.53 & 160 & -37.54 & 280 & -35.85 \\
\hline 50 & -31.23 & 170 & -39.23 & 290 & -34.73 \\
\hline 60 & -33.6 & 180 & -40.6 & 300 & -36.25 \\
\hline 70 & -32.34 & 190 & -38.27 & 310 & -35.59 \\
\hline 80 & -33.87 & 200 & -37.5 & 320 & -34.39 \\
\hline 90 & -35.65 & 210 & -36.68 & 330 & -37.67 \\
\hline 100 & -36.43 & 220 & -36.91 & 340 & -37.7 \\
\hline 110 & -37.76 & 230 & -35.57 & 350 & -35.27 \\
\hline
\end{tabular}

Penggambaran pola radiasi antena J-Pole pada Gambar 9 dan Gambar 10 membuktikan bentuk pola radiasi antena J-Pole hasil realisasi adalah omnidirectional. 


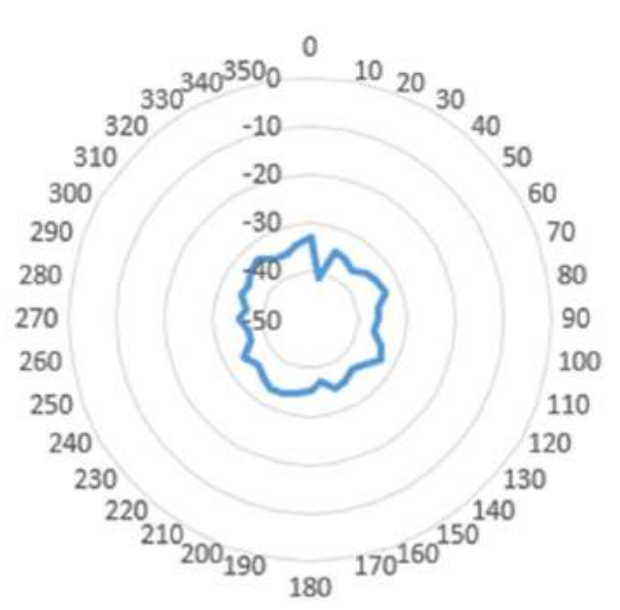

a). J-Pole 1

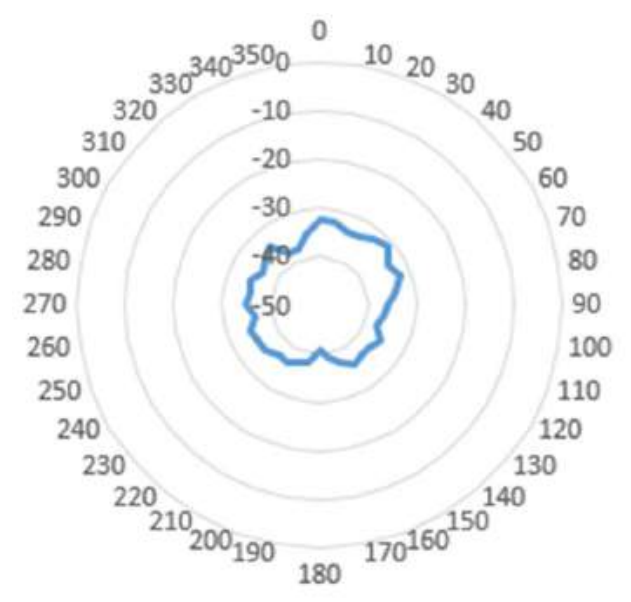

b). J-Pole 2

Gambar 9. Bentuk Pola Radiasi Antena J-Pole

Pada pola radiasi antena juga dapat dilihat menggunakan software MMANA-Gal seperti yang ada pada Gambar 10.

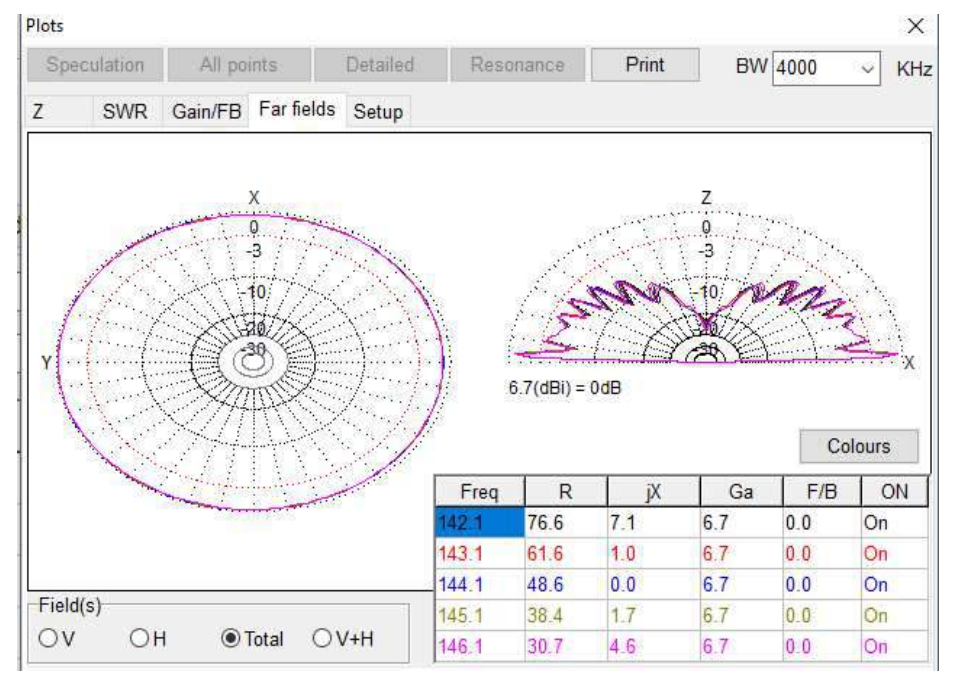

Gambar 10. Bentuk Pola Radiasi pada Software

\subsection{Analisis Daya Terima Antena J-Pole}

Pengukuran daya terima antena J-Pole dilakukan dengan skema seperti pada Gambar 11, dimana dibangkitkan sinyal dengan level daya $0 \mathrm{dBm}$ melalui signal generator yang dihubungkan dengan antena J-pole sebagai antena pengirim, sedangkan pada jarak 1 meter terdapat antena J-Pole lainnya sebagai penerima. Nilai daya terima hasil pengukuran ini menunjukkkan daya yang diterima oleh antena J-Pole ini sebesar $-19,16 \mathrm{dBm}$. 


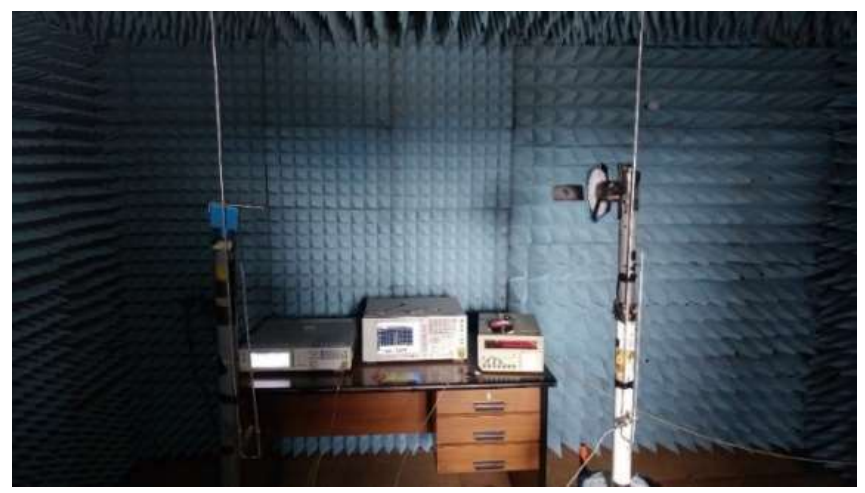

Gambar 11. Pengukuran Daya Antena J-Pole

\subsection{Analisis Jarak Jangkau}

Pengukuran ini bertujuan untuk mengetahui perbandingan jarak jangkauan HT maksimum untuk dapat berkomunikasi dengan baik. Pengukuran dilakukan sebanyak dua kali, dimana terlebih dahulu dilakukan pengukuran jarak jangkau maksimum saat menggunakan antena existing HT (Teno Tn-211), setelah itu baru digunakan antena J-Pole hasil realisasi. Hasil pengukuran jarak jangkau diperoleh jarak jangkau maksimum menggunakan antena existing adalah 1,1 km, sedangkan menggunakan antena J-Pole adalah 3,56 km. Plot lokasi dan jarak pengukuran jangkauan maksimum komunikasi HT dapat dilihat pada Gambar 12.

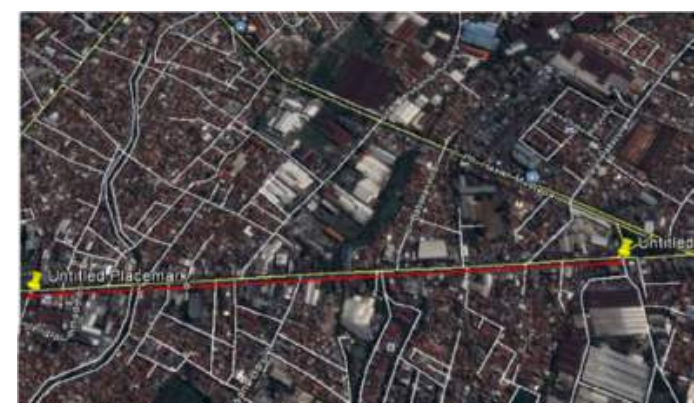

a). Penggunaan Antena Existing

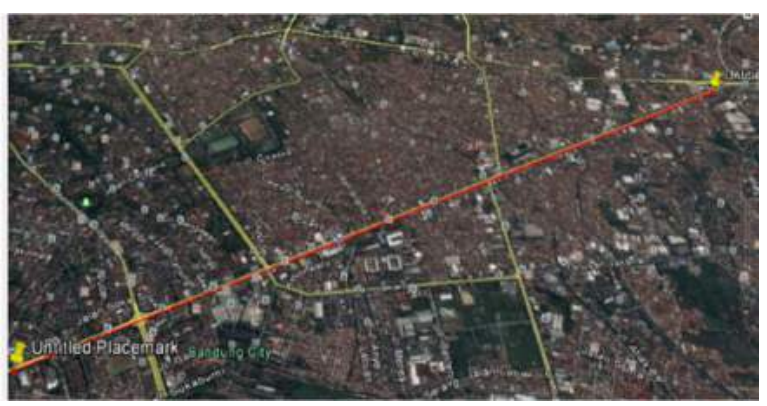

b). Penggunaan Antena J-Pole

\section{Gambar 12. Jarak Jangkau Maksimum Komunikasi HT}

Dari kedua data yang ada, maka dapat dilihat bahwa antena J-Pole memiliki jarak jangkau yang lebih jauh dari antena existing $\mathrm{HT}$. Hal ini dikarenakan antena J-Pole memiliki beberapa kelebihan dibandingkan dengan antena existing, khususnya dalam hal penguatan antena. Melalui penggunaan J-Pole yang diaplikasikan pada komunikasi HT ini, jarak jangkauan maksimum bertambah 2,46 km dari penggunaan antena existing $\mathrm{HT}$.

\section{KESIMPULAN}

Antena J-Pole telah berhasil direalisasikan, pengukuran level daya terima pada antena J-Pole menggunakan Signal Generator dengan level daya $0 \mathrm{dBm}$ dengan jarak satu meter antara kedua antena sebesar $-19,16 \mathrm{dBm}$. Pada pengukuran nilai penguatan antena diperoleh nilai sebesar 6,23 dB untuk J-Pole 1 dan 6,34 dB untuk J-Pole 2, sedangkan hasil simulasi menggunakan software MMANA-Gal, diperoleh nilai penguatan sebesar 6,7 dB. 
Nilai VSWR antena J-Pole antara hasil pengukuran, perhitungan berdasarkan teori dan penggunaan software simulasi tidak jauh berbeda, dimana hasil pengukuran diperoleh nilai VSWR sebesar 1,27 untuk J-Pole 1 dan 1,16 untuk J-Pole 2. Melalui perhitungan secara teori diperoleh nilai VSWR sebesar 1,3 untuk J-Pole 1 dan 1,17 untuk J-Pole 2. Nilai VSWR antena J-Pole melalui simulasi software MMANA-Gal didapatkan nilai sebesar 1,03.

Nilai dari return loss antena hasil perhitungan didapatkan sebesar $-18,58 \mathrm{~dB}$ untuk J-Pole 1 dan $-22,48 \mathrm{~dB}$ untuk J-Pole 2. Hasil penggambaran pola radiasi berdasarkan daya terima pada pengarahan antena yang diputar sampai dengan $360^{\circ}$ menunjukkan pola radiasi omnidirectional. Penggunaan antena J-Pole pada komunikasi HT memberikan peningkatan kinerja dalam hal penambahan jarak jangkau maksimal sebesar 2,46 km dari penggunaan antena existing.

\section{DAFTAR RUJUKAN}

Lesmana, R. (2013). Antena J Pole untuk $70 \mathrm{~cm}$ band dan $2 \mathrm{~m}$ band. YCOPE.

Akmal, M.A. (2014). Pembuatan Antena J-Pole dengan Frekuensi 144 MHz untuk Komunikasi Radio. Pekanbaru: Politeknik Caltex Riau.

Krismawardana, Y., Christyono, Y., \& Riyadi, M. A. (2015). Perancangan dan Analisis Antena J-Pole Dualband Dengan Variasi Bentuk "T" Untuk Komunikasi Radio Transceiver Pada Pita VHF dan UHF. Semarang: Universitas Diponegoro.

Irfan MJ. (2016). VSWR (Voltage Standing Wave Ratio) dan Return Loss. Dipetik pada tanggal 20 Maret 2018 dari: http://antenapropagasi.blogspot.com/2016/02/vswr-voltagestanding-wave-ratio-dan.html.

Ephirahmawati. (2013). Parameter antena. Dipetik pada tanggal 29 Agustus 2018 dari: https://ephirahmawati.wordpress.com/2013/02/19/parameter-antena/

K4abt. (1996). Have Fun Design Your Own J Pole For Any Band. Dipetik pada tanggal 2 April 2018 dari: http://www.hamuniverse.com/jpole.html.

Balanis, C.A. (20050. Antenna Theory : Analysis and Design - $3^{\text {rd }}$ edition. New York: John Willey and Sons.

Selvan. (2006). A Modified Three-Antenna Gain Measurement Method to Simplify Uncertainty Estimation, Progress in Electromagnetics Research, PIER 57, (pp.197-208). 